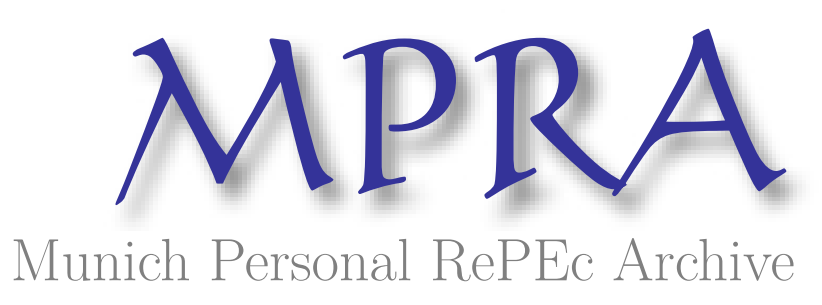

\title{
Gravity Model by Panel Data Approach: Empirical Evidence from Nigeria
}

\author{
Aliyu, Shehu Usman Rano and Bawa, Sani \\ Bayero Unviversity, Kano, Central Bank of Nigeria
}

6 October 2013

Online at https://mpra.ub.uni-muenchen.de/52549/

MPRA Paper No. 52549, posted 17 Jan 2019 16:55 UTC 


\title{
Gravity Model by Panel Data Approach: Empirical Evidence from Nigeria
}

\author{
Shehu U.R. Aliyu ${ }^{1}$ and Sani Bawa ${ }^{2}$
}

\begin{abstract}
Gravity trade model continue to be coveted for analysis of determinants trade flows among countries despite its lack of theoretical foundations. The main aim of the paper is to assess the determinants of flow of Nigeria's exports using longitudinal data from 1999 to 2012. Extrapolating from the empirical literature, the paper constructs Nigeria's gravity trade model comprising of 9 EU countries, BRICS countries, Canada, Japan and the US. Results from POOL and panel regressions - fixed and random effects show that market size, price index of destination countries positively drive trade flows in Nigeria, while relative factor endowment, economic similarities and geographical distance negatively affect Nigeria's trade flows. Furthermore, the paper found evidence in support of positive trade flows with the EU countries and negative trade flows with BRICS and on account of cultural difference. Findings show that Nigeria's exports follow Linder hypothesis. These have important implications for economic, socio-cultural and bilateral trade negotiations for better trade performance in Nigeria in the future.
\end{abstract}

JEL Classification: C23, F10, F15, L80

Keywords: Gravity model, trade flows, panel data, Linder hypothesis, relative factor endowment, economic bloc

\section{Introduction}

Nigeria evolved from a relatively buoyant agricultural economy, with its major exports in the pre-1960s to early 1970 s being non-oil agricultural produce, into a relatively rich, oildominated economy. Over the years, the proportion of crude oil exports in total exports had increased remarkably to become the dominant export commodity. The collapse of world oil prices and the sharp decline in the country's oil output resulting from a lowering of the country's OPEC quota in the early 1980s and the worsening economic and financial conditions that followed prompted the government to introduce the Structural Adjustment Programme (SAP) in July, 1986. SAPaimed to, among others, restructure and diversify the productive base of the economy so as to reduce dependency on the oil sector.

\footnotetext{
${ }^{1}$ Shehu U.R. Aliyu is a Professor of Financial Economics and Director, International Institute of Isla mic Banking and Finance (IIIBF), Bayero University, Kano, Nigeria. Mobile: +2348037875246, Emai 1 address: susaliyu.iiibfbuk@buk.edu.ng, director.iiibfbuk@buk.edu.ng

${ }^{2}$ Sani Bawa is a PhD candidate in the Department of Economics, Bayero University, Kano and works with the Statistics Department, Central bank of Nigeria (CBN). Mobile: +2348051248655 , email sani bawa@yahoo.com
} 
Notwithstanding, crude oil exports continue to remain the dominant commodity that drives the economic fortune of the economy. Accordingly, the directional flow of Nigeria's exports showed that prior to the 1970s, the United Kingdom (UK) was the main importer of Nigeria's agricultural produce-dominated commodity exports. With the commercial exploitation of crude oil that became the major export commodity, the Americas, led by the United States (US) was the major importer of Nigeria's crude oil followed by Western Europe, with France, Germany, Netherlands and Italy as leading importers. However, the share of Africa in Nigeria's trade remained significantly very low and unstable due to the noncomplementarities of goods (Mordi, et al. 2010), and among ECOWAS countries as well (Chete and Adewuyi, 2012).

Meanwhile, the recent past downturn in the industrialized countries have created uncertainty about the oil export markets in those economies. In the wake of increasing bilateral and multilateral arrangements globally and the bid to increase exports to compensate for the likely fall in the demand for oil from the industrialized economies, Nigeria entered into various forms of trade negotiations at the bilateral level. For instance, Nigeria has concluded trade agreements with many countries, including South Africa, Cuba, Vietnam, Tunisia, United States, Egypt, Algeria, Niger and Iran (Ukaoha, Ijemba and Ukpe, 2012). The major aims of these agreements is the promotion of trade, socioeconomic and cultural relations among the bilateral and multilateral groupings.

Against this backdrop, this paper examines the determinants of Nigeria's bilateral trade flows to some of its major trading partners by adopting the gravity model approach for the period 1999 to 2012. The major trading partners considered include: 9 European Union (EU) member countries, 5 countries that formed the BRICS and 3 other industrialized countries; the United States, Canada and Japan. Evidence shows that about75 percent of Nigeria's exports and 65 percent of its imports are directed to/from these countries in 2012. The paper utilizes the static fixed and the dynamic (GMM-system) random effects panel data approach for the estimation of the model. The rest of the paper is organized into four sections. Following this section is section two which reviews empirical studies and theoretical issues on the gravity trade model and presents stylized facts on the direction of Nigeria's exports and some key external sector indicators. Section threedescribes the research methodology, measurement of variables and sources of data used. Results presentation and discussion 
occupy section four while section five offers conclusion.

\subsection{Literature Review and Theoretical Issues}

The gravity model has demonstrated an excellent empirical robustness in describing trade flows in many countries, despite its often asserted lack of theoretical background (see Anderson and Wincoop, 2003). The model is analogous to the Newton's Law of Gravity, which states that the gravity between two objects is directly related to their masses and inversely related to the distance between them. In its most basic form, the gravity model in economics estimates the trade between two countries as a positive function of their economic sizes and a negative function of the distance between them (Ceglowski, 2006). The pioneering empirical models (Tinbergen, 1961; Poyhonen, 1963; Anderson, 1979; Caves, 1981; and Toh, 1982) also concur that geographical distance is an important determinant of gravity model, even though Brun, et al. (2005) found declining elasticity of trade to distance among industrial countries.

Empirical studies abound on application of gravity trade model in analyzing bilateral trade. $\mathrm{Yu}$ and Zietlow (1995), for instance, assess the factors affecting the level of trade between 14 countries in the Asia-Pacific region. They indicate that the traditional gravity variables of market size and physical distance, as well as political stability, cultural similarity, membership of the Association of Southeast Asian Nations (ASEAN) and being a newly industrialized country were the significant indicators of bilateral trade relationships in the pacific-basin. Similarly, Le, Nguyen and Bandara (1996) also show that the traditional variables are the major determinants of bilateral trade between the eighteen Asia - Pacific economies they considered.

Karemera, et al. (1999) investigate the determinants of trade flows in some selected commodity groups also in the Pacific Rim. Their study apply reduced-form gravity model derived from a general equilibrium model, the study showed that traditional gravitational variables such as incomes of importing and exporting countries, exchange rates, prices of the traded commodity, distance between trade partners and membership in regional trade groups were the major determinants of trade flows in the Pacific region. The study also show that membership in the ASEAN significantly increased trade creation among members as well as fostered trade diversion from members to non-members. Stone and Jeon (2000) discover that 
distance between the trading partners is a significant resistance factor for trade among the Asia-Pacific economies. They also indicated that the formation of Asia-Pacific Economic Cooperation (APEC) has enhanced economic interdependence in trade in the region. Brun, et al. (2005), however, found a decline in the elasticity of trade to distance when an augmented barrier to trade function was introduced, indicating that distance has died in bilateral trade. Utilizing a panel data involving 130 countries over the period 1962 - 1996, the authors show that the death of distance was shown to be largely confined to bilateral trade between rich countries. On the other hand, Anderson and Wincoop (2003) reveal that national borders reduce bilateral trade levels by plausible though substantial magnitudes.

Kimura and Lee (2006) analyze the determinants of bilateral services trade as compared to those of bilateral goods trade in 10 OECD countries and other economies trade. Findings suggest that the gravity equation performs better with international trade in services than with trade in goods. Also, geographical distance was consistently more important for services trade than for goods trade. As in Yu and Zietlow (1995), Karemera, et al. (1999) found that common membership in the same regional trade arrangement has a significant effect on trade. Results of an empirical study by Ceglowski (2006) also reveal that the standard gravity variables of economic size and geographical proximity, in addition to linguistic ties, are significant determinants of services trade in those countries.

Applying the gravity model in the Gulf Cooperation Council (GCC) countries, Boughanmi (2008) found that the GCC countries trade is twice more with each other than would be predicted by the basic gravity model. In another development, Insel and Tekce (2011) found that GCC countries trade are related to the wealth of the partner countries, but not their distance, mainly due to the nature of their exports and imports, the characteristics of the region and development in transport facilities. Similarly, in Asia, Kien (2009) examines the determinants of trade flows of ASEAN Free Trade Area (AFTA) members. The study indicates that GDP, population, language and geographic distance explain export flows among the 6 ASEAN members studied. Kabir and Salim (2010) estimate factors that influence bilateral trade flows in the four founding members of BIMSTEC (Bangladesh, India, Sri Lanka and Thailand) with their key trading partners. Findings show that gravity model successfully explains the pattern of trade in the bloc. 
Ekanayake, Mukherjee and Veeramacheneni (2010) apply the augmented gravity model specification in Kabir and Salim (2010) to assess the effects of regional trade agreements on trade flows among 19 Asian countries. They show that real GDP, population and distance between trading partners influence Asian exports. Kepaptsoglou, et al. (2010) document an excellent review of early contributors to empirical literature on gravity models for a 10-Year (1999-2009) period. The review shows that while most of the empirical studies utilized panel and cross sectional data a number of estimation techniques were applied; OLS, 2SLS, GLS, POOL regression, fixed and random effects, GMM, TOBIT, and or a combination of some of these techniques. Most recurring exogenous variables from the review include among others: gdp, gdp per capita, distance, FTA, cultural similarities, population, common border, etc.

Recently, Tripathi and Leitao (2013) examine India's trade flows with 20 major trading partners using a gravity model for the period 1998 to 2012. The results reveal that gravity model explains the pattern of the bloc's trade. Specifically, economic size, cultural proximity, common border and political globalization had significant impact on India's bilateral trade. Similarly, Yu, Tang and Xu (2013) apply an extended gravity model for component trade in ACFTA (ASEAN and PRC) and results show that free trade agreement leads to a substantially higher and more pronounced bilateral trade flows between ASEAN and PRC than what a conventional gravity model would predict.

Empirical studies on the Nigerian economy have been quite few. Aliyu (2007), and Adewuyi and Bankole (2012) apply the gravity model specification to evaluate Nigeria's bilateral trade flows with India and China separately. Aliyu (2007) found that income levels, exchange rates and index of openness are strong drivers of bilateral trade flows for India, but not for Nigeria. On the other hand, Adewuyi and Bankole (2012) show that the economic sizes and levels of tariffs of both China and Nigeria play a major role in promoting trade between them. The review concludes that gravity model is very popular among researchers and has been extensively used for assessing trade policy implications overthe last 40 years because of its considerable empirical robustness and explanatory power.

\subsection{Stylized Facts on Nigeria's External Sector}

Nigeria is located in West African sub region, bordering the Republic of Benin, Cameroun, Niger, Chad and a vast coastline of the Atlantic Ocean. It is a member of the West African 
Monetary Zone (WAMZ), Economic Community of West African States (ECOWAS), the African Union (AU) and the World Trade Organization (WTO). It has equally signed a number of bilateral trade agreements with a number of countries of the world. Belonging to these associations no doubt, offer vast potentials for sub regional, regional and global economic integration and cooperation for mutual benefits. Table 1 summarizes the direction and value of Nigeria's exports to its major trading partners.

\begin{tabular}{|c|c|c|c|c|c|}
\hline \multirow{3}{*}{ COUNTRY } & \multirow{2}{*}{\multicolumn{5}{|c|}{ EXPORT FLOWS (In US\$ Million) }} \\
\hline & & & & & \\
\hline & 1999 & 2004 & 2006 & 2009 & 2012 \\
\hline Belgium & 26.14 & 58.60 & 114.35 & 161.17 & 67.03 \\
\hline France & 683.77 & $1,092.26$ & $2,261.49$ & $2,378.68$ & $4,323.82$ \\
\hline Germany & 188.94 & 339.90 & $1,585.32$ & $1,478.20$ & $5,144.08$ \\
\hline Italy & 224.20 & 538.04 & 934.89 & 992.56 & $1,949.59$ \\
\hline Netherlands & 130.06 & 388.08 & $1,313.50$ & $1,810.08$ & $9,098.24$ \\
\hline Portugal & 291.86 & 773.61 & 881.14 & $1,600.83$ & $1,083.35$ \\
\hline Spain & 876.49 & $2,327.02$ & $4,325.29$ & $3,566.12$ & $8,210.49$ \\
\hline Sweden & 4.09 & 26.96 & 2.64 & 152.35 & 990.61 \\
\hline United Kingdom & 190.03 & 191.39 & 332.71 & 891.71 & $5,421.20$ \\
\hline Total EU Countries & $2,615.58$ & $5,735.86$ & $11,751.33$ & $13,031.70$ & $36,288.40$ \\
\hline Brazil & 738.20 & $3,499.34$ & $3,943.10$ & $4,765.94$ & $8,012.21$ \\
\hline Russia & 4.23 & 6.67 & 1.47 & 4.54 & 22.99 \\
\hline India & $2,264.30$ & 50.02 & $4,807.56$ & $5,158.93$ & $12,766.50$ \\
\hline China & 165.90 & 420.52 & 252.50 & 816.57 & $1,151.05$ \\
\hline South Africa & 201.66 & 803.79 & $1,322.70$ & $1,929.20$ & $3,745.42$ \\
\hline Total BRICS Countries & $3,374.28$ & $4,780.35$ & $10,327.33$ & $12,675.18$ & $25,698.18$ \\
\hline Canada & 260.55 & 73.58 & 652.72 & 406.41 & $2,015.30$ \\
\hline Japan & 188.83 & $1,298.30$ & 873.50 & 483.65 & $4,332.49$ \\
\hline United States & $4,219.73$ & $15,556.55$ & $26,326.64$ & $17,943.00$ & $17,748.55$ \\
\hline Total 17 Major Trade Partners & $10,658.97$ & $27,444.64$ & $49,931.53$ & $44,539.94$ & $86,082.92$ \\
\hline \multicolumn{6}{|l|}{ Percentage Share } \\
\hline EU Countries & 18.9 & 18.4 & 20.5 & 23.0 & 31.8 \\
\hline BRICS Countries & 24.4 & 15.3 & 18.0 & 22.3 & 22.5 \\
\hline United States & 30.5 & 49.9 & 45.8 & 31.6 & 15.6 \\
\hline All Countries & 76.9 & 88.1 & 86.9 & 78.5 & 75.5 \\
\hline
\end{tabular}

Traditionally, the United Kingdom (UK) prior to the 1970s was the main importer of Nigeria's agricultural produce-dominated commodity exports. Later with the discovery of crude oil in commercial quantity, which became the major export commodity in volumes and values, the United States turned out as the major importer of Nigeria's crude oil, followed by Western Europe. Evidences in Table 1 show that exports from Nigeria to its major trading 
blocs has been increasing quite steadily. Total exports to the 17 countries, which was US\$10,658.97 million in 1999, increased to US\$49, 931.53 million and US\$86, 082.92 million in 2006 and 2012, respectively. The total exports to the 17 countries constituted about 75.5 percent of Nigeria's total exports in 2012. Similarly, Nigeria's exports to the nine EU countries increased from US\$2, 615.58 million in 1999 to US\$11, 751.33 million and US\$36, 288.40 million, respectively, in 2006 and 2012. The largest trading partners in the EU countries in 2012 were the Netherlands, Spain, the UK and Germany.

Nigeria's export flows to the BRICS economies have also been increasing over the years, with India and Brazil remaining the largest importers of Nigeria's crude oil during the period. Total exports to the BRICS economies rose to US\$25, 698.18 million, constituting about 22.5 percent of Nigeria's total exports, from US\$4, 780.35 million in 2004. The United States has been the Nigeria's largest importer among the 17 trading partners during the period. Nigeria's exports to the United States constituted about 50 percent of its total exports in 2004, but declined steadily to 15.6 percent in 2012 .

\begin{tabular}{|c|c|c|c|c|}
\hline \multicolumn{5}{|c|}{ TABLE 2: NIGERIA'S EXTERNAL SECTOR DATA } \\
\hline & Exports $^{1}$ & Imports $^{1}$ & Exchange Rates $^{2}$ & External Reserves $^{2}$ \\
\hline Year & (US\$ Million) & (US\$ Million) & (N/US\$ 1.00) & (US\$ Million) \\
\hline 1999 & $13,855.60$ & $8,587.80$ & 92.69 & $5,424.60$ \\
\hline 2000 & $20,975.00$ & $8,721.30$ & 102.11 & $9,386.10$ \\
\hline 2001 & $17,261.00$ & $11,585.80$ & 111.94 & $10,267.10$ \\
\hline 2002 & $15,107.00$ & $7,547.00$ & 120.97 & $7,681.10$ \\
\hline 2003 & $19,887.00$ & $10,853.40$ & 129.36 & $7,467.78$ \\
\hline 2004 & $31,148.00$ & $14,164.00$ & 133.50 & $16,955.02$ \\
\hline 2005 & $55,144.47$ & $21,313.88$ & 132.15 & $28,279.06$ \\
\hline 2006 & $57,443.88$ & $26,760.07$ & 128.65 & $42,298.11$ \\
\hline 2007 & $65,133.06$ & $37,576.00$ & 125.83 & $51,333.15$ \\
\hline 2008 & $80,615.31$ & $42,378.14$ & 118.57 & $53,000.36$ \\
\hline 2009 & $56,741.90$ & $33,906.28$ & 148.90 & $42,382.49$ \\
\hline 2010 & $84,000.00$ & $44,235.27$ & 150.30 & $32,339.25$ \\
\hline 2011 & $114,500.00$ & $56,000.00$ & 153.86 & $32,639.78$ \\
\hline 2012 & $114,000.00$ & $51,000.00$ & 157.50 & $43,830.42$ \\
\hline \multirow{2}{*}{\multicolumn{5}{|c|}{$\begin{array}{r}\text { Sources: } 1 \text { Internal Financial Statistics, IMF } \\
2 \text { Central Bank of Nigeria Statistical B }\end{array}$}} \\
\hline & & & & \\
\hline
\end{tabular}

Evidences in Table 2 however, show that Nigeria's total exports witnessed decline between 2000 and 2002, in response to the decline in the international prices of crude oil during the period. Consequently, export promotion policies were adopted between 2002 and 2007 to enhance the marketability of exports through product diversification, standardization and quality improvement, strengthening and improving the institutional framework to provide better support services to exporters and providing export incentives. Accordingly, total 
exports rose from US\$19, 887.00 million in 2003 to US\$65, 133.06 million in 2007. Total exports increased further to US\$114,000.00 million in 2012.

Nigeria's total imports, which stood at US\$8,587.8 million in 1999 , increased to US\$14, 164.0 million and US\$42, 378.14 million in 2004 and 2008, respectively. It however, declined to US\$33, 906.28 million in 2009 reflecting the decline in oil prices and the subsequent reduction in total exports. The upward trend in imports was largely attributable to the depreciation of the exchange rate of the naira vis-à-vis the US dollar and the increased tempo in economic activities, especially the deregulation of the communication and downstream oil sectors. The import structure indicated that capital goods and raw materials constituted the bulk of total imports.

Meanwhile, the exchange rate of the Naira depreciated to N111.94/US dollar in 2001, from N92.69/US dollar in 1999. In spite of the re-introduction of the Dutch Auction System (DAS) in July 2002 to stem the depletion of external reserves and realign the naira exchange rate, the rate depreciated to N120.97/US dollar in 2002. However, the exchange rate appreciated between 2005 and 2008, largely reflecting the moderation in the demand pressure at the foreign exchange market. The rate, however, depreciated to N157.50/US dollar in 2012. Similarly, the level of Nigeria's external reserves as at end 1999 stood at US\$5, 424.60 million, which almost doubled to US\$10, 267.10 million in 2001. However, following severe pressure witnessed in the external sector, external reserves fell to US\$7, 467.78 million in 2003, but rose to US\$28, 279.06 million and US\$53,000.36 million in 2005 and 2008, respectively. It finally stood at $\$ 43,830.42$ as at December, 2012. It is clear from the above stylized fact that a more robust approach of analyzing the flow of Nigeria exports is desirable. It is pertinent, for instance, to know what factors matter most for sustained trade flows for Nigeria vis-à-vis its major trading partners. The model that is more readily available is the gravity trade model, which over the years, has proved very useful in this regards.

\subsection{Research Methodology}

Modeling of bilateral trade has developed over the last 40 years, Kepaptsoglou et al. (2010). They argue that gravity model is very popular among researchers and has been extensively used for assessing trade policy implications because of its considerable empirical robustness and explanatory power. Critiquing the gravity model, however, Bergstrad (1985) argues that despite the model's consistently high statistical explanatory power, its use for predictive 
purposes has been inhibited owing to an absence of strong theoretical foundations. Filipinni and Molini (2003) further opine that while the gravity model has often been characterized as "facts without theory", consistency of its results with facts makes it very popular for practical applications.

The Ordinary Least Squares (OLS) method has traditionally been the usual technique for estimating the coefficients of the gravity model specification in its log linear form. While OLS is still implemented for analyzing and evaluating policies according to Siliverstovs and Schumacher (2008), researchers have indicated methodological and modeling flaws in the development of gravity models using OLS. In view of these, Peridy (2005) employs variety of modeling techniques (OLS, fixed effects, random effects, HTM, GMM and ABB) and comes up with a number of comments by comparing their results. Similarly, Arellano and Bond (1991), Ahn and Schmidt (1992) and Keane and Runkle (1992) advocate for the use of the GMM methodology for the estimation of dynamic panel models or panel models with predetermined rather than exogenous right-hand variables. This paper utilizes both the POOL regressions and GMM based panel estimations.

Early econometric approaches for modeling trade flows havefocused on the gravity model specification which is analogous to Newton's Law of Gravity, which states that the gravity between two objects is directly related to their masses and inversely related to the distance them.

$$
F_{i j}=G \frac{Y_{i}^{\alpha}}{D_{i j}} \underline{Y}_{i}^{\beta}
$$

Where $F_{i j}$ denotes the flow of trade from country $i$ to country $j . Y_{i}$ and $Y_{j}$ are the economic sizes of the two countries, which is usually measured as the gross domestic product (GDP), or percapita GDP. $D_{i j}$ measures the distance between countries where $G$ is a gravitational constant. The above equation can be slightly modified to incorporate additional variables and expressed into a log linear regression model as follows:

$$
\ln x_{i j}=\alpha_{0}+\alpha_{1} \ln y i+\alpha_{2} \ln y_{j}-\alpha_{3} \ln d i j+\alpha_{4} \ln \delta_{i j}+\varepsilon_{i j}
$$

Equation (2) above depicts the relation between trade flows (which can be bilateral, imports, exports or total trade) and explanatory variables which refer to the sizes of the trading 
partners' economies (mass variables), their proximity (distance) and a vector of other factors $\delta_{i j}$, believed to be promoting or discouraging trade between them. $\alpha_{0}$ and $\alpha_{1}-\alpha_{4}$ are elasticities. $\varepsilon_{i j}$ is the disturbance term $\log \left(\varepsilon_{i j}\right)$ is assumed to be iid with zero mean $\mathrm{E}\left(\log \left(\varepsilon_{i j}\right)\right)$ $=0$, and a constant variance. Some of these variables identified in the literature include: population; size similarity, originally motivated by Helpman (1987); GDP percapita, which according to Bergstrand (1985) serve as a proxy for the capital - endowment ratio. In line with the above justifications from the literature, equation (2) is further slightly modified to include additional variables. This is specified in the next sub section.

\subsection{Specification of Empirical Model}

On the basis of the above theoretical and empirical views, the empirical model of this paper is specified as follows:

$$
\begin{aligned}
& \ln x_{i j t}=\alpha_{0}+\alpha_{1} \ln y_{i t}+\alpha_{2} \ln y_{j t}+\alpha_{3} \ln p_{i t}+\alpha_{4} \ln p_{j t}+\alpha_{5} \ln r f e_{i j t}+\alpha_{6} \ln \operatorname{sim}_{i j t}+ \\
& \alpha_{7} \ln \text { pop }_{j t}+\alpha_{8} \ln d_{i j t}+a_{9} \ln d u m 1 e u_{i j t}+\alpha_{10} \operatorname{lndum} 2 \text { brics }_{i j t}+\alpha_{11} d u m 3 \operatorname{lan}_{i j t}+\varepsilon_{i j t}
\end{aligned}
$$

From equation (3) above, $(i)$ and $(j)$ denote exporter - Nigeria, and importer country, that is, a total of 17 countries - Belgium, Brazil, Canada, China, France, Germany, India, Italy, Japan, Netherlands, Portugal, Russia, South Africa, Spain, Sweden, United Kingdom and United States while $t$ denotes time. Exports data were sourced from IMF's Direction of Trade Statistics (DOTS). Other variables are explained as follows: Market size variable $y_{i}$, for country Nigeria, which is the source of exports, and $y_{j}$ importer, which is the destination country is measured as respective country's real gross domestic product (GDP). Data was obtained from the International Financial Statistics (IFS). International crude oil price and producer price index and were used as measures of relative prices for local $(i)$ and destination (j) countries; RFE indicates relative factor endowment, and $\mathrm{SIM}^{3}$ stands for similarity index. The later two variables can be defined as follows:

$$
\begin{aligned}
\operatorname{RFE}_{\mathrm{ij}, \mathrm{t}} & =\left|\operatorname{InPGDP}_{\mathrm{i}, \mathrm{t}}-\operatorname{InPGDP}_{\mathrm{j}, \mathrm{t}}\right| \\
\mathrm{SIM}_{\mathrm{ij}, \mathrm{t}} & =\ln \left\{1-\left[\frac{\ln \left(\mathrm{GDP}_{\mathrm{i}}\right)}{\ln \left(\mathrm{GDP}_{\mathrm{i}}+\mathrm{GDP}_{\mathrm{i}}\right)}\right]^{2}-\left[\frac{\ln \left(\mathrm{GDP}_{\mathrm{j}}\right)}{\ln \left(\mathrm{GDP}_{\mathrm{i}}+\mathrm{GDP}_{\mathrm{i}}\right)}\right]^{2}\right\}
\end{aligned}
$$

\footnotetext{
${ }^{3}$ Breuss and Egger (1999), Egger (2000 and 2002), and Serlenga and Shin (2007) define SIM as in equation (5) above.
} 
$\mathrm{RFE}_{\mathrm{ij}}$ takes a minimum of zero if both countries exhibit equal GDP or production ${ }^{4}$. The Linder hypothesis predicts that an increased difference between per capita GDP of source and destination countries will decrease trade of monopolistically competitive products under the assumption of differentiated tastes, and thus $\alpha_{5}<0$. The range of SIM is given by, $0<\mathrm{SIM}_{\mathrm{ij}, \mathrm{t}}$ $<0.5$; where 0.5 means 'equal' and zero implies 'absolute divergence' in country size. Krugman (1981) shows that the nature of trade depends on similarity of countries in terms of factor endowment (which supports the Linder hypothesis), and trade between countries increasingly becomes intra industry as they become more similar.

As a proxy for transportation cost, longer geographical distance implies a higher level of transportation cost and thus reduces trade flows (Bergstrand 1985; Srivastava and Green 1986). However, Nitsch (2000) proposed a more detailed method for calculating intracountry distances as a function of country size. In this paper, geographical distance between countries is estimated by airline distance in kilometers between major cities and data for this were obtained from www.happyzebra.com/distance-calculator. Population figures were obtained from the World Development Indicators (WDI) for destination countries only. For binary variables; cultural similarity according to Srivastava and Green (1986) is measured by a dummy variable, that is, 1 if both countries share the same dominant religion and language, or 0 if otherwise. In this paper, all the dummy variables used assume a value of 1 for EU countries, BRICS countries, and English as an official language, and a value of 0 if otherwise.

\subsection{Results Presentation and Analysis}

The above model was estimated using data spanning over a period of 14 years; 1999 to 2012 . Results from preliminary investigations presented in Table $1 \mathrm{~A}$ in the appendix reveal that exports, market size, population have relatively higher log mean ranging between 18.0 and 27.7. Others, with the exception of the binary variables have moderate log mean of between 3.0 and 8.6. The series show evidence of both negative and positive skewness and in some few cases, the Kurtosis statistic is above 3 which suggest evidence of fat tails. Low probability values of Jarque-Bera statistic in most of the series refute the null hypothesis of

\footnotetext{
${ }^{4}$ The Linder (1961) hypothesis implies that the greater the difference in per capita income between two countries, the lower the share of the bilateral intra-industry trade. Bergstrand (1990), for instance, shows that the gravity equation can explain the impact of differences of national and per capita income and capital-labour ratio on the degree of intra-industry trade between two countries.
} 
normality in the distribution.

Empirical results from the estimation of equation 3 above are presented in Table 3. Results from POOL regression model were based on two-stage least square/instrumental variable method while the panel - FE and RE, were based on panel GMM with cross section random effect in the latter. However, the impact of time invariant regressors; distance, trading bloc and language were dropped in the FE model but well accommodated in the RE. Oddly, Wei and Frankel (1997) reject the inclusion of country-pair dummies a priori on the basis that doing so would undermine their efforts at estimating the effects of variables that are constant over the sample period.

Table 3: Regression Estimates of Gravity Trade Model for Nigeria

POOL

Regression

Panel Regression

\begin{tabular}{|c|c|c|c|}
\hline Coefficient & POOL & FE & RE \\
\hline Constant & $\begin{array}{l}-24.48 * * \\
(-2.521)\end{array}$ & $\begin{array}{l}-82.079 \\
(-0.793)\end{array}$ & $\begin{array}{l}-23.883 \\
(-0.803)\end{array}$ \\
\hline $\ln y_{i}-$ Exporter's gdp & $\begin{array}{c}1.838 * * * \\
(4.827)\end{array}$ & $\begin{array}{c}1.841 \\
(1.391)\end{array}$ & $\begin{array}{l}1.858 \\
(1.496)\end{array}$ \\
\hline $\ln y_{j}-$ Importers gdp & $\begin{array}{l}1.220 * * * \\
(5.353)\end{array}$ & $\begin{array}{c}0.124 \\
(0.177)\end{array}$ & $\begin{array}{l}1.889 * * \\
(2.147)\end{array}$ \\
\hline $\ln p_{i}-$ crude oil price & $\begin{array}{c}-0.298 * * \\
(-2.125)\end{array}$ & $\begin{array}{c}-0.264 \\
(-0.381)\end{array}$ & $\begin{array}{l}-0.292 \\
(-0.419)\end{array}$ \\
\hline $\ln p_{j}-$ producer price index & $\begin{array}{l}0.378 * * * \\
(8.715)\end{array}$ & $\begin{array}{c}0.549 \\
(0.991)\end{array}$ & $\begin{array}{c}0.373 * * * \\
(3.826)\end{array}$ \\
\hline In $R F E_{i j}$ - Relative factor endowment & $\begin{array}{c}-0.793 * * \\
(-2.534)\end{array}$ & $\begin{array}{l}-0.946^{*} \\
(-1.772)\end{array}$ & $\begin{array}{c}-0.799 \\
(-1.381)\end{array}$ \\
\hline ln $S I M_{i j}$ - Similarities & $\begin{array}{l}-2.516^{*} \\
(-1.947)\end{array}$ & $\begin{array}{l}-0.706 \\
(-0.285)\end{array}$ & $\begin{array}{l}-2.294 * * \\
(-2.594)\end{array}$ \\
\hline ln $\mathrm{pop}_{j}$ - Population & $\begin{array}{c}0.188 \\
(0.580)\end{array}$ & $\begin{array}{c}2.986 \\
(0.568)\end{array}$ & $\begin{array}{c}0.183 \\
(0.312)\end{array}$ \\
\hline In $d i s_{i j}$ - Geographical distance & $\begin{array}{c}-3.882 * * * \\
(-23.38)\end{array}$ & dropped & $\begin{array}{l}-3.911 * * * \\
(-7.051)\end{array}$ \\
\hline dumleu - European Union & $\begin{array}{l}1.125^{* * *} \\
(7.232)\end{array}$ & dropped & $\begin{array}{c}1.231 \\
(1.479)\end{array}$ \\
\hline dum2brics - BRICS & $\begin{array}{l}-2.109 * * * \\
(-9.983)\end{array}$ & dropped & $\begin{array}{c}-2.147 * * * \\
(-3.379)\end{array}$ \\
\hline dum3cul - Language & $\begin{array}{l}-4.201 * * * \\
(-24.75)\end{array}$ & dropped & $\begin{array}{c}-4.223 * * * \\
(-5.170)\end{array}$ \\
\hline Adjusted R-squared & 0.573 & 0.674 & 0.553 \\
\hline DW & 1.313 & 1.937 & 1.340 \\
\hline Hausman Test & & & 0.00 [prob 1.00] \\
\hline
\end{tabular}

Source: Researcher's computation using Eviews version 7.0

Theoretical values of $\mathrm{t}$ in parenthesis.

$* * *, * *$ and $*$ indicate significance at the 1,5 and $10 \%$, respectively. 
In line with expectation, market size elasticities of both the source and destination countries are consistent and statistically significant in the POOL and FE regressions. It is clear from the estimates, for instance, that a simultaneous 1 percent increase in real gdp of both countries will increase Nigeria's exports by 1.8 percent and increase imports by 1.2 to 1.8 percent in the recipient country. This concur with findings reported by empirical studies on positive and significant effect of market size on the importing and exporting countries' bilateral trade flows (Geraci and Prewo 1977; Bergstrand 1985; Srivastava and Green 1986). Intuitively, it suggests that the market size of importing country is capable of absorbing its imports; while the market size of the exporting country is equally capable of manufacturing products needed by foreign customers.

The price levels of nations affect trade activities, (Thomas, 1985). A decrease in world crude oil price lowers production cost at industry level and is expected to increase exports, while a rise in the producer price index in the country of destination is trade promoting. Estimates of price elasticities in the POOL regression show robust and statistically significant coefficients and although only the importer's price elasticity is significant in the RE model, the magnitude of the impact are virtually the same across the model. Furthermore, the absolute sum of the two price elasticities is less than unity, thus not fulfilling the Marshal-Lerner ${ }^{5}$ hypothesis for Balance of payment equilibrium condition (BOP). The elasticity of relative factor endowment (RFE) measured in equation (4) is quite strong and bears the hypothesized sign in both POOL and FE regressions. Although this rejects the Heckscher-Ohlin-Samuelson (HOS) theorem, it however, indicates that Linder hypothesis successfully explains the pattern of Nigeria's exports. Serlenga and Shin (2007) and Kabir and Salim (2010) found RFE to be positive and significant in the traditional FEE, REE estimations, which in their own case favors the HOS theorem. Similarly, SIM elasticity measured in equation 5 is found to be both significant and correctly signed in POOL and RE regressions which further supports the Linder hypothesis. According to the hypothesis, an increased difference between per capita GDP of source and destination countries will decrease trade of monopolistically competitive products under the assumption of differentiated tastes, and thus $\alpha_{6}<0$.

\footnotetext{
${ }^{5}$ When the sum of price elasticicities of demand for exports and imports in absolute terms is greater than unity, devaluation will improve the country's BOP, i.e., $e_{x}+e_{m}>1$
} 
Population is another indicator of market size - Brodzicki (undated) and Kien (2009). Results from the three estimations, however, yield theoretically consistent but statistically insignificant elasticity of population. Kien (2009) reports negative coefficient for importer's and exporter's population in his empirical studies. The sign of geographical distance elasticity is robust and statistically significant at the 1 percent level and bears hypothesized sign across. This supports Balassa (1966), Balassa and Bauwens (1987), who found negative correlation between geographical distance and trade. Similarly, studies by Kien (2009), Shepotylo (2010) and Salim and Kabir (2010) report analogous findings on log of distance in their empirical studies on ASEAN free trade area, Ukraine and BIMSTEC countries, respectively. Comparably, a 1 percent increase in log of distance lowers trade by 3.88 POOL, and 3.91 - random effect.

On trading blocs, dummy elasticities show strong evidence of positive impact EU membership on exports and a negative impact for BRICS countries. Although the former is consonance with the hypothesized value, the latter, especially given the market size and level of industrial activities in the bloc is anti theoretical. On other qualitative coefficients, Frankel and Rose (1998) demonstrate the importance of cultural, distance, language, religion, etc., in analyzing bilateral trade flows. Balassa (1966) and Balassa and Bauwens (1987) found a positive sign for some of these factors. Accordingly, in Table 3 above, the coefficient of elasticity for language (cultural similarity) across the two estimations is robust, negatively signed and statistically significant at the 1 percent level. Lastly, result from robustness tests show that the adjusted $\mathrm{R}^{2}$ is strong and this suggests that the vector of exogenous variables account for over 55 percent variations in the level of exports. The DW statistic also suggests absence of serial correlation in the idiosyncratic random error, while the Hausman test accepts the hypothesis that random effect specification is better. The cross section random effect tests yield high probabilities indicating significant difference in the variances of FE and RE estimates. On the whole, above results situate well within the body of empirical findings in the area. Thus, it is safe to conclude that gravity trade model adequately explains the flow of bilateral trade between Nigeria and its trading partners.

\subsection{Conclusion}

Gravity trade model has been widely employed in the analysis of bilateral trade despite its lack of theoretical foundations. In the aftermath of the global financial crisis, Nigeria has 
pursued bilateral trade negotiations with a number of non-traditional trading partners. Evidences from stylized facts show significant improvements in the flow of export trade over the last one decade. In 2012 alone, for instance, about 75 percent of Nigeria's exports and 65 percent of its imports are directed to/from Europe, the United States and Asia. This paper therefore assesses the determinants of Nigeria's export trade using panel data from 1999 to 2012 comprising of 9 EU countries, BRICS countries and 3 others; Canada, Japan and the United States.

The results from empirical analysis demonstrate the relevance of gravity trade model in determining the Nigeria's exports performance. Market size of both source and destination countries, export and imports prices, relative factor endowment and similarities in economic structures exert significant effect on the gravity model. In particular, findings lend support to the famous Linder hypothesis. Generally, as these findings situate well within the body of empirical studies reported in the above, it unambiguously indicate the relevance of gravity trade model in predicting flow of Nigeria's exports.

\section{References}

Ahn, S.C. and Schmidt, P. (1992). Efficient Estimation of Models for Dynamic Panel Data, Journal of Econometrics 68(1), 5-27.

Adewuyi, A. O. and Bankole, A. S. (2012). Are There Potential Economic Benefits From China - Nigeria Trade Agreements? African Journal of Economic Policy, Vol. 19, No. 1, June.

Aliyu, S. U. R. (2008). "Bilateral Trade Talk between Nigeria and India: A Recipe”, Nigerian Journal of International Affairs, Volume 34, Number 1, pp. 93 - 104, Available at: http://www.niianet.org/njai2008.htm

Anderson, J. E. (1979). A Theoretical Foundation for the Gravity Equation, The American Economic Review, Vol. 69, No. 1, pp. $106-116$.

Anderson, Kym. (1991). "Is Asian-Pacific Trade Bloc Next". Journal of World Trade 25, no. 4: 27-40. Asian Wall Street Journal. "APEC Takes Steps to Boost Role, But Limits Remain in Near Term". p. 6.

Anderson, J. E. and Wincoop, E. (2003). Gravity with Gravitas: A Solution to the Border Puzzle, The American Economic Review, Vol. 93, No. 1, March, pp. 170 - 192.

Arellano, M., Bond, S. (1991). Some tests of specification for panel data: Monte Carlo evidence and an application to employment equations. Review of Economic Studies 58(2), 277-297. 
Balassa, B. (1966). Tariff reductions and trade in manufactures among industrial countries. American Economic Review 56(3), 466-473.

Balassa, B., Bauwens, L. (1987). Intra-industry specialization in multi-country and multiindustry framework. The Economic Journal 97 (388), 923-939.

Beckerman, W. (1956). Distance and the Pattern of Inter-European Trade. Review of Economics and Statistics, 38: 31-40.

Bergstrand, Jeffrey H. (1985). "The Gravity Equation in International Trade: Some Microeconomic Foundations and Em pirical Evidence". Review of Economics and Statistics 67: 474-81.

Boughanmi, H. (2008). The Trade Potential of the Arab Gulf Cooperation Countries (GCC): A Gravity Model Approach, Journal of Economic Integration, Vol. 23, No. 1, March, pp. 42 $-56$.

Brada, Josef C. and Jose A. Mendez. (1983). "Regional Economic Integration and the Volume of Intra-Regional Trade: A Comparison of Developed and Developing Country Experience". Kyklos 36: 589-603.

Brewer, Thomas L. (1985). A Comparative Analysis of the Fiscal Policies of Industrial and Developing Countries-Policy Instability and Governments-Regime Instability.Journal of Comparative Economics, No. 2: 191-96.

Brodzicki, Tomasz (undated). Extended Gravity Panel Data Model of Poland's Foreign Trade, Economics of European Integration Department, Faculty of Economics, University of Gdańsk, Ul. Armii Krajowej 119/121, 81-824 Sopot, Poland.

Brun, J. F., Carrere, C., Guillaumont, P. and Melo, J. (2005). Has Distance Died? Evidence from a Panel Gravity Model, The World Bank Economic Review, Vol. 19, No. 1, pp. 99 120.

Caves, R. (1981). Intra-Industry Trade and Market Structure in the Industrial Countries, Oxford EconomicPapers, Vol. 33, No. 2, pp. 203 - 223.

Ceglowski, J. (2006). Does Gravity Matter in a Service Economy? Review of World Economics, Vol. 142, No. 2, July, pp. $307-329$.

Chete, L.N. and Adewuyi, A. O. (2012). Dynamics of Trade between Nigeria and Other ECOWAS Countries, Brookings Africa Growth Initiative.

Cotsomitis, John, Chris DeBresson, and Andy Kwan. (1991)."A Re-Examination of the Technology Gap Theory of Trade: Some Evidence from Time Series Data for O.E.C.D. Countries". Weltwirtschaftliches Archiv 127, no. 4: 792-99.

Cushman, David O. (1990). "US Bilateral Trade Equations: Forecasts and Structural Stability". Applied Economics 22, no. 8: 1093-102.

Drysdale, Peter and Ross Garnaut. (1982). Trade Intensities and the Analysis of Bilateral 
Trade Flows in a Many-Country World: A Survey. Hitotsubashi Journal of Economics 23: 62-84.

Ekanayake, E. M., Mukherjee, A. and Veeramacheneni, B. (2010). Trade Blocks and the Gravity Model: A Study of Economic Integration Among Asian Developing Countries, Journal of Economic Integration, Vol. 25, No. 4, December, pp. 627 - 643.

Filippini C, Molini V. (2003). The determinants of East Asian trade flows: a gravity equation approach. Journal of Asian Economics, 14(5): 695-711.

Frankel, Jeffrey A. (1992). Is Japan Creating a Yen Bloc in East Asia and the Pacific? Working Paper No. 4050. Cambridge, MA: National Bureau of Economic Research, Inc., pp. $1-32$.

Frankel, J. A., Rose, A. K., (1998). The endogeneity of the optimum currency area criteria. The Economic Journal 108(449), 1009-1025.

Geraci, Vincent J. and Wilfried Pre wo (1977). Bilateral Trade Flows and Transportation Costs. Review of Economics and Statistics 59, no. 1: 67-74.

Gruber, William, et al. (1967). The R\&D Factor in International Trade and International Investment of United States Industries, Journal of Political Economy, pp. 21-37.

Helpman E. (1987). "Imperfect competition and international trade: evidence from fourteen industrial countries". Journal of Japan International Economics; 1(1): 62-81.

Hofstede, Geert. (1991). Cultures and Organizations, Cambridge University Press,

Institutional Investor. (1980). "Institutional Investor's 1980 Country Credit Ratings". pp. 283.

IMF, (1987). International Financial Statistics: Supplement on Trade Statistics. Washington, D.C

International Monetary Fund. (1991). Direction of Trade Statistics Yearbook, Washington, D.C.

Insel, A. and Tekce, M. (2011). Bilateral Trade Flows in the Gulf Cooperation Council Countries: What Happened to the Middle East Integration After 2003? Journal of Economic Integration, Vol. 26, No. 2, June, pp. $244-275$.

Jain, Subhash C. (1990). International Marketing Management.Third edition. Boston: PWSKent Publishing Company.

Kabir, M. and Salim, R. (2010). Can Gravity Model Explain BIMSTEC's Trade? Journal of Economic Integration, Vol. 25, No. 1, March, pp. 143 - 165.

Karemera, D., Smith, W. I., Ojah, K and Cole, J. A. (1999). A Gravity Model Analysis of the Benefits of Economic Integration in the Pacific Rim, Journal of Economic Integration, Vol. 14, No. 3, September, pp. $347-367$. 
Keane, M.P. and Runkle, D.E. (1992). On the Estimation of Panel-Data Models with Serial Correlation when Instruments are not Strictly Exogenous. Journal of Business and Economic Statistics, Vol.10, No. 1, pp. 1-9.

Keesing, D.B. (1968). Population and Industrial Development: Some Evidence from Trade Patterns. American Economic Review 58, no. 3: 448-55.

Kepaptsoglou, K., Karlaftis, M. G. and Tsamboulas, D. (2010). The Gravity Model Specificationfor Modeling International Trade Flows and Free Trade Agreement Effects: A 10-Year Review of Empirical Studies, The Open Economics Journal, (3), pp. 1 - 13.

Kien, N. T. (2009). Gravity Model by Panel Data Approach: An Empirical Application with Implications for the ASEAN Free Trade Area, ASEAN Economic Bulletin, Vol. 26, No. 3, December, pp. $266-277$.

Kimura, F. and Lee, H. (2006). The Gravity Equation in International Trade in Services, Review of World Economics, Vol. 142, No. 1, April, pp. 92 - 121.

Le, Q. P., Nguyen, D. T. and Bandara, J. S. (1996). Vietnam's Foreign Trade in the Context of ASEAN and the Asia-Pacific Region: A Gravity Approach, ASEAN Economic Bulletin, Vol. 13, No. 2, November, pp. 185 - 199.

Linder, S.B. (1967). Trade and Trade Policy for Development, London: Pall Mall Press.

Mordi, C.N.O., Englama, A. and Adebusuyi, B. S. (2010). The Changing Structure of the Nigerian Economy, Research Department, Central Bank of Nigeria.

Nitsch V. (2000). National borders and international trade: evidence from the European Union. Canadian Journal of Economics; 33(4): 1091-105.

Oddly, Wei and Frankel (1997). cited in I-Hui Cheng and Howard J. Wall "Controlling for Heterogeneity in Gravity Models of Trade and Integration.

Peridy N. (2005). Toward a Pan-Arab free trade area: assessing trade potential effects of the Agadir agreement. Dev Econ; XLIII-3:329- 45.

Poyhonen, P. (1963). A Tentative Model for the Volume of Trade Between Countries, Weltwirtschaftliches Archiv, Vol. 90, No. 1, pp. 93 - 99.

Siliverstovs, B. and Schumacher, D. (2008). Estimating gravity equations: to log or not to $\log$ ? Empirical Economics; 36(3): 645-69.

Shepotylo, O. (2010). A Gravity Model of Net Benefits of EU Membership: The Case of Ukraine, Journal of Economic Integration, Vol. 25, No. 4 (December 2010), pp. 676-702

Srivastava, Rajendra and Robert Green (1986). Determinants of Bilateral Trade Flows, The Journal of Business 59, no. 4 (October 1986): 623-40.

Stone, S. F. and Jeon, B. N. (2000). Foreign Direct Investment and Trade in the Asia Pacific Region: Complementarity, Distance and Regional Economic Integration, Journal of 
Economic Integration, Vol. 15, No. 3, September, pp. 460 - 485.

Tinbergen, J. (1961). Shaping the World Economy: Suggestions for an International Economic Policy. The Twentieth Century Fund, New York.

Toh, K. (1982). A Cross-Section Analysis of Intra-Industry Trade in US Manufacturing Industries, Weltwirtschaftliches Archiv, Vol. 118, No. 2, pp. 281 - 301.

Tripathi, S. and Leitao, N. C. (2013). India's Trade and Gravity Model: A Static and Dynamic Panel Data, MPRA Paper No. 45502.

Ukaoha, K., Ijemba, I. and Ukpe, A. (2012). Reducing Poverty in Nigeria Through Effective Trade Agreements, The Norwegian Council for Africa.

van Hulst, Noe, et al. (1991). "Exports and Technology in Manufacturing Industry". Weltwirtschaftliches Archiv 111, no. 2: 246-83.

Yu, C. J. and Zietlow, D. S. (1995). The Determinants of Bilateral Trade Among Asia-Pacific Countries, ASEAN Economic Bulletin, Vol. 11, No. 3, March, pp. 298 - 305.

Yu, Sheng, Tang, Hsiao Chink and Xu, Xinpeng (2013). The Impact of ACFTA on ASEANPRC Trade: Estimates Based on Extended Gravity Model for Component Trade, Journal of Applied Economics, in view. 
Table A1 Summary of Statistics

\begin{tabular}{lccccccccc}
\hline & & & \multicolumn{9}{c}{ Std. } & \multicolumn{3}{c}{ Jarque- } \\
& Mean & Max & Min & Dev. & Skewness & Kurtosis & Bera & Prob & Obs. \\
\hline Expt & 20.231 & 24.297 & 9.1663 & 2.306 & -1.4921 & 6.5790 & 211.72 & 0.0000 & 238 \\
$y_{i}$ & 25.471 & 25.903 & 25.094 & 0.2595 & 0.1069 & 1.7326 & 16.106 & 0.0003 & 238 \\
$y_{j}$ & 27.756 & 30.235 & 25.900 & 1.0609 & 0.289 & 2.7102 & 4.091 & 0.1292 & 238 \\
$p_{i}$ & 3.9301 & 4.7259 & 2.9685 & 0.5725 & -0.1653 & 1.6509 & 18.811 & 0.0000 & 238 \\
$p_{j}$ & 4.3666 & 5.115 & -0.9162 & 0.8640 & -3.3035 & 14.349 & 1681.4 & 0.0000 & 238 \\
pop $_{j}$ & 18.039 & 21.019 & 15.996 & 1.4051 & 0.4845 & 2.6815 & 10.146 & 0.0062 & 238 \\
rfe & 3.0564 & 4.7924 & 0.0058 & 1.1967 & -1.0605 & 3.1481 & 44.078 & 0.0000 & 238 \\
sim & 0.5472 & 0.6857 & 0.0273 & 0.1338 & -1.4535 & 4.6338 & 108.42 & 0.0000 & 238 \\
dis & 8.651 & 9.471 & 8.1930 & 0.3769 & 0.687 & 2.4196 & 21.717 & 0.0000 & 238 \\
dum1eu & 0.5384 & 1.000 & 0.000 & 0.4995 & -0.1543 & 1.023 & 39.005 & 0.0000 & 238 \\
dum2brics & 0.2820 & 1.000 & 0.000 & 0.4509 & 0.9686 & 1.9383 & 47.584 & 0.0000 & 238 \\
dum3lan & 0.5940 & 1.000 & 0.000 & 0.4921 & -0.3828 & 1.1466 & 39.209 & 0.0000 & 238 \\
\hline \hline
\end{tabular}

Researcher's computation 